\title{
LARVICIDAL AND REPELLENT EFFECT OF LEAF AND STEM EXTRACTS FROM CESTRUM NOCTURNUM (SOLANACEAE) AGAINST CULEX PIPIENS L. (DIPTERA: CULICIDAE)
}

MOSTAFA I. HASSAN $^{1}$, TAREK M. Y. EL-SHEIKH ${ }^{1}$, MOUNEER S. AMER ${ }^{1}$, WALAA A. MOSELHY ${ }^{2}$ and AHMED Z. SHEHATA ${ }^{1}$

${ }^{1}$ :Department of Zoology, Faculty of Science(boys), Al-Azhar University, Nasr City, Cairo, Egypt.

${ }^{2}$ : Department of Zoology, Faculty of Science(girls), Al-Azhar University, Nasr City, Cairo, Egypt.

E-mail: mostafa012@gmail.com

\begin{abstract}
The larvicidal and repellent effects of the crude ethanol and acetone leaf and stem extracts of the widely grown plant, Cestrum nocturnum, against Culex pipiens $3^{\text {rd }}$ instar larvae and adults were evaluated. Ethanolic leaves extract was found to be the most effective against the larvae, with $\mathrm{LC}_{50}$ value of $377.1 \mathrm{ppm}$ followed by acetone leaves and stems extracts with $\mathrm{LC}_{50}$ values of 484.2 and $994.0 \mathrm{ppm}$; respectively and finally ethanolic leaves extract with $\mathrm{LC}_{50}$ value of 1043.8ppm. The plant extracts tested reduced the percentages of pupation and adult emergence. Also, varying degrees of morphogenic abnormalities in immature and adult stages were observed. Moreover, the acetone stem extract showed a highly delayed toxic effect on pupae resulted from the treated larvae, where the pupal mortality $\%$ was $100 \%$ at all concentrations used. All concentrations of plant extracts used in the present study exhibited a repellent activity against the adult mosquitoes. The repellent action of the plant extracts tested was varied depending on plant part, solvent and the dose of the extract. Because of the high larvicidal and pupicidal potential of plant extracts tested, they can be used as effective alternatives to the existing synthetic pesticides for the control of Culex pipiens.
\end{abstract}

Key words: Ethanolic extract, Acetone extract, Petroleum ether extract, Toxicity, Cupressus sempervirens, Culex pipiens.

\section{Introduction}

Insect-transmitted disease remains a major cause of illness and death worldwide. Mosquitoes alone transmit disease to more than 700 million people annually (Taubes, 2000). Therefore, the control of mosquitoes is an important public health concern around the world. For example, Culex pipiens is the main vector of Rift valley fever virus (Darwish and Hoogastrall, 1981), Wuchereria bancrofti (Gad et al., 1996) and Western Nile virus (Pelah et al., 2002). The only efficacious approach to minimizing the incidence of these diseases is to eradicate and control mosquito 
vectors, mainly by applying insecticides to larval habitants, and educating the public (Corbel et al., 2004).

Chemical control is an effective strategy used extensively in daily life. Synthetic insecticides are today at the forefront of mosquito controlling agents. Nevertheless, controlling the mosquitoes has become complicated because of their resistance to synthetic insecticides, as well as the toxicity of insecticides to fish and other nontarget organisms (Wattanachai and Tintanon, 1999; Rohani et al., 2001). There is an urgent need to develop new materials for controlling mosquitoes in an environmentally safe way, using biodegradable and target-specific insecticides against them.

Due to environmental concern on use of existing synthetic insecticides for vector control and further risk of development of widespread insecticides resistance in disease vector; interest on possible use of environment friendly natural products such as extracts of plants or plant parts increased for vector control Jawale et al., (2010).

Sukumar et al. (1991) listed 346 plant species of 276 genera and 99 families which have been tested against mosquitoes for various effects such as toxicity, growth inhibition, ovipositional determinacy and repellency. This list includes many species from Solanaceae family. Recently, Ghosh and Chandra (2006) and Ghosh et al. (2008) evaluated phytosteroidal compound of mature leaves of day jasmine, Cestrum diurnum (Solanaceae: Solanales) against larvae of Culex quinquefasciatus and Anopheles stephensi. The plant extracts used in the present study have been pointed as a promising alternative to combat this vector. In this work we evaluate the potential of extract from $C$. nocturnum as larvicide and repellent against $3^{\text {rd }}$ instar larvae and adult of Culex pipiens.

\section{Materials and Methods}

\section{Mosquito as colony:}

Culex pipiens used in this study were obtained from Medical Entomology Research Center, Doki, Cairo, Egypt. They were reared for several generations, in the insectary of medical entomology at the Department of Zoology faculty of science, Al-Azhar University under controlled conditions at temperature of $27 \pm 2^{\circ} \mathrm{C}$, relative $70 \pm 10 \%$ R.H. and 12-12 light-dark regime. Adult mosquitoes were kept in $(30 \times 30 \times 30 \mathrm{~cm})$ wooden cages and daily provided with sponge pieces soaked in 
$10 \%$ sucrose solution for a period of 3-4 days after emergence. After this period the females were allowed to take a blood meal from a pigeon host, which is necessary for laying eggs (anautogeny). Plastic oviposition cup $(15 \times 15 \mathrm{~cm})$ containing dechlorinaed tap water was placed in the cage. The resulting egg rafts picked up from the plastic dish and transferred into plastic pans $(25 \times 30 \times 15 \mathrm{~cm})$ containing 3 liters of tap water left for $24 \mathrm{~h}$. The hatching larvae were provided daily with fish food as a diet. This diet was found to be the most preferable food for the larval development and a well female fecundity, (Kasap and Demirhan, 1992).

\section{Plant tested:}

The plants selected for this study are listed in table (1) which included common name, scientific name, family, habitat, collection site.

Table (1): Plant used as ethanolic and acetone extracts against Culex pipiens larvae and adult.

\begin{tabular}{|c|c|c|c|c|}
\hline Common name & Scientific name & family & Habitat & collection site \\
\hline Night jessamen & Cestrum nocturnum & Solanaceae & Desert & $\begin{array}{l}\text { Sadat city (Cairo- } \\
\text { Alexandria desert road) }\end{array}$ \\
\hline
\end{tabular}

\section{Extraction of plant materials:}

The plant parts after they collected from natural habitat, were left to dry at room temperature $\left(27-31^{\circ} \mathrm{C}\right)$ and pulverized to powder separately in a hammer mill. The extraction was performed using 70\% ethanol, and acetone solvents. One hundred grams of powder from each part of the plant for each solvent separately were extracted five times with $300 \mathrm{ml}$ of aqueous $70 \%$ ethanol, and acetone at room temperature. After 24 h., the supernatants were decanted, filtrated through whatman filter paper No. 5 . and dried in a rotary evaporator. The dry extracts were weighed and kept in deep freezer $\left(-4^{\circ} \mathrm{C}\right)$ till used for experiments.

\section{Experimental bioassay:}

\subsection{Larvicidal activity:}

In order to study the toxicity of the concerned plant extracts, the tested material of the ethanolic extracts was dissolved in $0.1 \mathrm{ml}$ of $70 \%$ ethanol, while the tested material of acetone extracts was dissolved in 2 drop of Tween. 80 as emulsifier to facillate the dissolving of tested material in water. Different range of concentrations of each concerned extract was prepared in order to detect mortalities. All tested 
materials were performed in $100 \mathrm{ml}$. of dechloronated tap water contained in $200 \mathrm{ml}$ plastic cups. Then, third $3^{\text {rd }}$ instar larvae were put immediately into plastic cups contained different concentrations of extracts. At least three replicates were usually used for each tested concentration. All plastic cups were incubated under controlled conditions of $27 \pm 2^{\circ} \mathrm{C}, 70 \pm 10 \%$ relative humidity and $12-12$ light-dark regime. Control larvae received $0.1 \mathrm{ml}$ of $70 \%$ ethanol or 2 drop of Tween.80 in $100 \mathrm{ml}$ water. Mortality was recorded daily and dead larvae and pupae removed until adult emergence. Abnormal pupae were removed daily and placed in labeled glass vials containing $70 \%$ ethanol and one drop of glycerine then photographed under binocular microscope.

\subsection{Repellent /antifeedant action:}

Standard cages $(20 \times 20 \times 20 \mathrm{~cm})$ were used to test the repellent activity of plant extracts. Different weights from each extract was dissolved in $2 \mathrm{ml}$ (70\% ethanol or water + drop of Tween) in glass $4 \times 4 \mathrm{~cm}$ to prepare different concentrations. One $\mathrm{ml}$ from each concentration was directly applied onto $5 \times 6 \mathrm{~cm}$ of ventral surface of pigeon after removing feathers from the abdomen to evaluate the repellency against C. pipiens, compared with commercial repellent (Off!) 15 \% Deet (N. N. diethyl toulamide) (Johnson Wax Egypt) as a positive control. After 10 minutes of treatment, the treated pigeons were placed in the cages containing at least 20 Culex pipiens starved females 5-7 d-old for $4 \mathrm{~h}$. Control tests were carried out alongside with the treatments using ethanol or water. Each test was repeated three times to get a mean value of repellent.

\section{Criteria studied:}

5.1. Biological activity of plant extracts against the larval stages: The larvae were observed daily until pupation and adult emergence to estimate the following parameters:

5.1.1. Larvicidal activity: Larval mortality percent was estimated by using the following equation (Briggs, 1960): larval mortality $\%=A-B / A \times 100$ where: $A$ $=$ number of tested larvae, $\mathrm{B}=$ number of tested pupa.

5.1.2. Pupation rate: The pupation percent was estimated by using the following equation: pupation $\%=\mathrm{A} / \mathrm{B} \times 100$ where: $\mathrm{A}=$ number of pupae, $\mathrm{B}=$ number of tested larvae. 
5.1.3. Pupal mortality: The pupal mortality percent was estimated by using the following equation: pupal mortality $\%=\mathrm{A}-\mathrm{B} / \mathrm{A} \times 100$ where: $\mathrm{A}=$ number of produced pupae, $\mathrm{B}=$ number of observed adults.

5.1.4. Adult emergence: The emerged males and females adults were counted and the adult emergence percent was calculated by using the following equation: Adult emergence $\%=\mathrm{A} / \mathrm{B} \times 100$ where $: \mathrm{A}=$ number of emerged adults, $\mathrm{B}=$ number of tested pupae.

5.1.5. Malformative effects: Pupal malformation was estimated by any change in color, size, shape or failure to develop to adult stage (pupal-adult intermediate). All malformed pupae were counted and removed immediately. The pupal malformation percent was calculated by using the following equation: pupal malformation $\%=\mathrm{C} / \mathrm{A} \times 100$ where: $\mathrm{C}=$ number of malformed pupae, $\mathrm{A}=$ number of tested pupae.

\section{Repellent activity of plant against adult stage:}

After treatments, the number of fed and unfed females were counted and calculated according to Abbott, (1925). Repellency \% = [\% A - \% B / $100-\%$ B $] \times$ 100 Where: $A=$ percent of unfed females in treatment, $B=$ percent of unfed females in control

\section{Statistical analysis :}

Statistical analysis of the data was carried out according to the method of lentner et al., (1982). $\mathrm{LC}_{50}$ was calculated using multiple linear regression (Finney, 1971).

\section{Results}

\section{Plant extract tested:}

Data given in table (2) indicated the amounts of dry $70 \%$ ethanol and acetone soluble material from 100 gm of different plant parts. As shown from the results, these amounts were varied from one part to another. In addition, ethanolic plant extracts produced higher weights followed by acetone extracts generally. The highest weight ( $8.2 \mathrm{gm}$ ) was obtained from the ethanolic leaves extract, while the lowest weight of the extracts was obtained from the acetone stems extract ( $3.1 \mathrm{gm})$.

Table (2): The weight of dry $70 \%$ ethanol and acetone soluble material from $100 \mathrm{gm}$ of C. nocturnum and their parts. 
MOSTAFA I. HASSAN, et al.,

\begin{tabular}{cccc}
\hline \hline \multirow{2}{*}{ Plant } & \multicolumn{2}{c}{ Plant part used } & \multicolumn{2}{c}{ Weight of extract (gm) } \\
\cline { 3 - 5 } & & Ethanolic & Acetone \\
\multirow{2}{*}{ C. nocturnum } & Leaves & 8.21 & 6.72 \\
\cline { 2 - 4 } & Stems & 6.92 & 3.13 \\
\cline { 2 - 4 }
\end{tabular}

2. Biological activity of plant extracts against the larval stage of Culex pipiens:

The biological activity (larvicidal activity, pupal rate, pupal mortality, total larval and pupal mortality, adult emergence) of ethanolic and acetone extracts against the $3^{\text {rd }}$ instar larvae of $C$. pipiens has been studied. The results may be arranged as follows:

\subsection{Ethanolic extract of leaves and stems:}

Data given in tables (3\&4) indicated the biological activity of ethanolic extract of $C$. nocturnum (leaves and stems), respectively against the $3^{\text {rd }}$ instar larvae of $C$. pipiens.

The highest larval mortality percent (100\%) occurred at the highest concentrations (2500 and 3500ppm), while the lowest mortality percent (23.3 and $26.7 \%$ ) occurred at the lowest concentrations (200 and 250ppm), respectively compared to $13.3 \%$ for the control.

The pupation percent decreased as the concentration level of ethanolic extract of C. nocturnum (leaves and stems) increased. The pupation percent recorded $0.0 \%$ at 2500 and 3500ppm and 76.7 and $73.3 \%$ at the lowest concentrations (200 and $250 \mathrm{ppm}$ ), respectively compared to $86.7 \%$ of the control.

Data given in table (3) revealed that there is no effect of ethanolic extract of $C$. nocturnum (leaves) on the mortality percent of pupae developed from treated larvae. Also, it is cleared from table (4), that ethanolic extract of $C$. nocturnum (stems) has low toxic effect against the pupae resulted from the treated larvae especially at the concentrations (2000 and $500 \mathrm{ppm}$ ), where the pupal mortality percent was 14.3 and $10.0 \%$; respectively compared to $3.8 \%$ for the control group.

As shown from the results in table (4) the total mortality percent of larvae and pupae were: 93.3, 80.0, 53.3, 50.0 and $30.0 \%$ at the concentrations 2500, 2000, 1000, 500 and 250 ppm, respectively compared to 16.7 for control group. 
The adult emergence percent was not affected at all concentrations used by ethanolic extract of $C$. nocturnum (leaves) as compared with the control. On the other hand, the adult emergence percent was affected only by ethanolic extract of $C$. nocturnum (stems) at the concentration (2000ppm) where it reduced to $85.7 \%$, compared to $96.2 \%$ for the untreated larvae.

The lethal effect of the ethanolic extract of $C$. nocturnum (leaves and stems) did not extend to the adult stage because no adult mortality percent had been observed.

The ethanolic extract of $C$. nocturnum (leaves and stems) did not induce malformation effects on pupae resulted from treated larvae.

From the aforementioned results it is obvious that the toxicity values of the tested ethanolic extracts of different plant parts of $C$. nocturnum based on $\mathrm{LC}_{50}$ values (Table 5 and Fig 1) may be arranged in a descending order as follows: leaves $>$ stems.

Table (3): Effect of ethanolic extract of Cestrum nocturnum (leaves) on mortality percent of different stages of Culex pipiens.

\begin{tabular}{ccccccc}
\hline $\begin{array}{c}\text { Conc. } \\
\text { ppm }\end{array}$ & $\begin{array}{c}\text { Larval } \\
\text { Mortality \% }\end{array}$ & $\begin{array}{c}\text { Pupation } \\
\%\end{array}$ & $\begin{array}{c}\text { Pupal } \\
\text { Mortalit } \\
\%\end{array}$ & $\begin{array}{c}\text { Larval and } \\
\text { pupal } \\
\text { Mortality \% }\end{array}$ & $\begin{array}{c}\text { Adult } \\
\text { Emergence \% }\end{array}$ & $\begin{array}{c}\text { Adult } \\
\text { Mortality \% }\end{array}$ \\
\hline 2500 & 100.0 & - & - & - & - & - \\
2000 & 93.3 & 6.7 & 0.0 & 93.3 & 100.0 & 0.0 \\
1000 & 90.0 & 10.0 & 0.0 & 90.0 & 100.0 & 0.0 \\
500 & 76.7 & 23.3 & 0.0 & 76.7 & 100.0 & 0.0 \\
250 & 33.3 & 66.7 & 0.0 & 33.3 & 100.0 & 0.0 \\
200 & 23.3 & 76.7 & 0.0 & 23.3 & 100.0 & 0.0 \\
\hline \hline Control & 13.3 & 86.7 & 0.0 & 13.3 & 100.0 & 0.0 \\
\hline
\end{tabular}

No. of tested larvae $=30$; Conc. $=$ Concentration; $\mathrm{ppm}=$ particle per million

Table (4): Effect of ethanolic extract of Cestrum nocturnum (stems) on mortality percent of different stages of Culex pipiens.

\begin{tabular}{|c|c|c|c|c|c|c|c|}
\hline $\begin{array}{c}\text { Conc. } \\
\text { ppm }\end{array}$ & $\begin{array}{c}\text { Larval } \\
\text { Mortality } \\
\%\end{array}$ & $\begin{array}{c}\text { Pupation } \\
\%\end{array}$ & $\begin{array}{c}\text { Pupal } \\
\text { Mortality } \\
\%\end{array}$ & $\begin{array}{c}\text { Malformed } \\
\text { pupae } \\
\%\end{array}$ & $\begin{array}{c}\text { Larval } \\
\text { and pupal } \\
\text { Mortality } \\
\%\end{array}$ & $\begin{array}{c}\text { Adult } \\
\text { Emergence } \\
\%\end{array}$ & $\begin{array}{c}\text { Adult } \\
\text { Mortality } \\
\%\end{array}$ \\
\hline
\end{tabular}




\begin{tabular}{cccccccc}
$\mathbf{3 5 0 0}$ & 100.0 & - & - & & - & - & - \\
$\mathbf{2 5 0 0}$ & 93.3 & 6.7 & 0.0 & 0.0 & 93.3 & 100.0 & 0.0 \\
$\mathbf{2 0 0 0}$ & 76.7 & 23.3 & 14.3 & 14.3 & 80.0 & 85.7 & 0.0 \\
$\mathbf{1 0 0 0}$ & 53.3 & 46.7 & 0.0 & 0.0 & 53.3 & 100.0 & 0.0 \\
$\mathbf{5 0 0}$ & 33.3 & 66.7 & 10.0 & 10.0 & 50.0 & 90.0 & 0.0 \\
$\mathbf{2 5 0}$ & 26.7 & 73.3 & 4.5 & 4.5 & 30.0 & 95.5 & 0.0 \\
\hline \hline Control & $\mathbf{1 3 . 3}$ & $\mathbf{8 6 . 7}$ & $\mathbf{3 . 8}$ & $\mathbf{0 . 0}$ & $\mathbf{1 6 . 7}$ & $\mathbf{9 6 . 2}$ & $\mathbf{0 . 0}$ \\
\hline
\end{tabular}

No. of tested larvae, Conc., ppm, : see footnote of table (3)

Table (5): Relative efficiency of ethanolic extract of different Parts of Cestrum nocturnum against $C$. pipiens larvae.

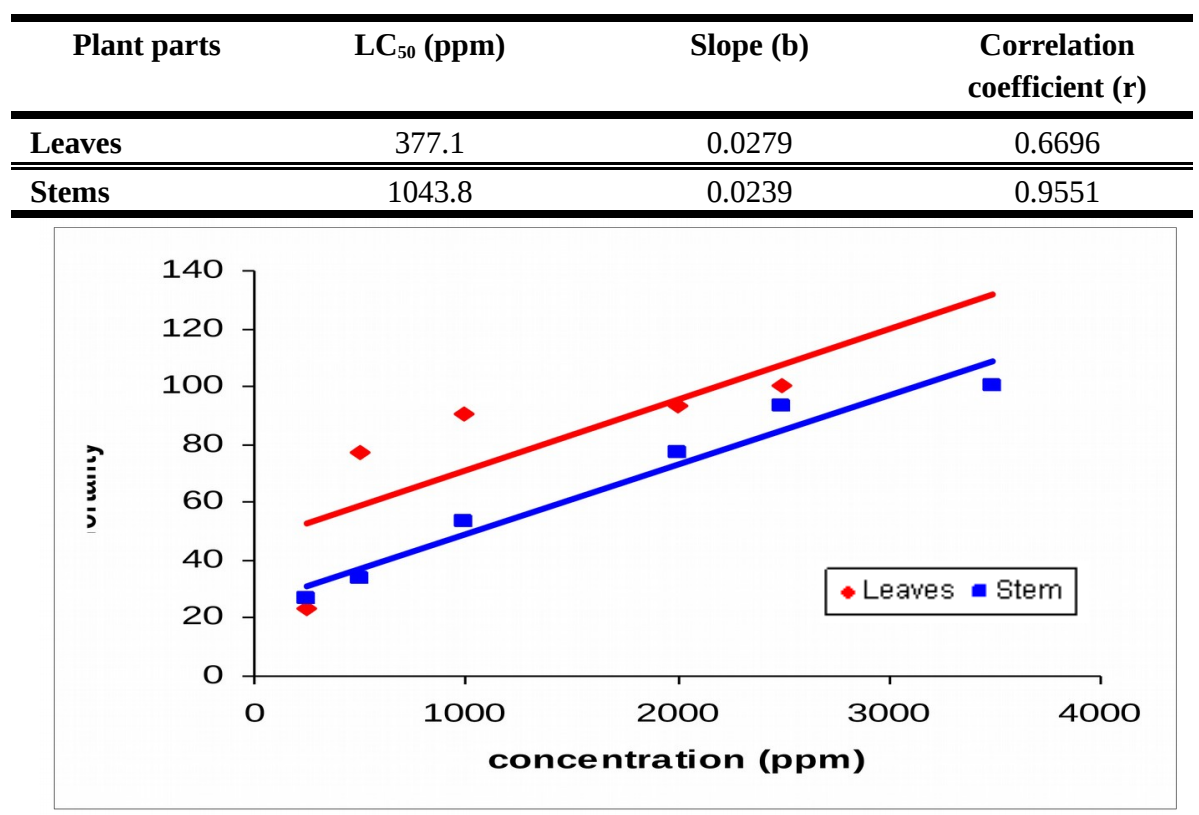

Fig. (1): Regression line of larval mortality of $C$. pipiens treated with different concentrations from ethanolic extracts of $C$. nocturnum.

\section{2. Acetone extract of leaves and stems:}

Data given in table (6\&7) indicated the biological activity of acetone extract of $C$. sempervirens (Leaves and stems), respectively against the $3^{\text {rd }}$ instar larvae of $C$. pipiens.

Leaves extract caused Complete larval mortality (100\%) at the highest concentration (2000ppm), meanwhile the lowest value (26.7\%) was occurred at the lowest concentration (250ppm) compared to $10.0 \%$ for the control group. The highest mortality percent (100\%) caused by stem extract was at the concentration (3000ppm) and the lowest mortality percent (10.0\%) was at the concentration (125ppm).Compared to $6.7 \%$ for the control. 
At the highest and lowest concentrations: (2000 and 250ppm) of leaves extract the pupation percent was 0.0 and $73.3 \%$; respectively vs. $90 \%$ for the untreated group (Table 6). The pupation \% recorded 10.0 and $90.0 \%$ at the highest and lowest concentration (2000 and 125ppm) of stem extract; respectively compared to $93.3 \%$ for the control group.

The lethal effect of acetone extract (leaves) was extended to the pupal stage at the all concentrations used: 1500, 1000, 500 and 250ppm, where the pupal mortality percent was 100.0, 87.5, 93.3 and $90.9 \%$; respectively, vs. $0.0 \%$ for the control. Data given in table (7) revealed that there was a very highly toxic effect of acetone extract (stems) on the survivorship of pupae developed from the treated larvae, where the mortality \% was $100.0 \%$ at all concentrations used, while it was 3.6 for the control group.

The total larval and pupal mortality were found to be highly affected by acetone extract (leaves). The highest mortality (100.0\%) was noticed at the concentration; 1500ppm and the lowest mortality (93.3\%) was noticed at the concentration (250ppm); respectively compared to $10.0 \%$ at the control group.

A remarkable reduction in the percentage of adult emergence from pupae produced by treated larvae with the acetone extract (leaves). The adult emergence percent $(0.0 \%)$ was occurred at the concentration $1500 \mathrm{ppm}$, meanwhile the percent increased to 12.5, 6.7 and 9.1\% at the concentrations 1000, 500 and 250ppm, respectively compared to $100.0 \%$ of the control group. On the other hand, the adult emergence was not observed by acetone extract (stems) because this extract induced $100 \%$ pupal mortality at all concentrations used.

As shown from the results (table 7) the toxicity of acetone extract (leaves) extended to the adult stage, where the adult mortality percent was $100 \%$ at $1000 \mathrm{ppm}$, while at the two lowest concentration (500 and 250ppm) the mortality percent was $0.0 \%$ as in the control group.

The results recorded in table $(7 \& 8)$ showed that the acetone extract ( leaves and stems) induced high \% of malformation on the pupae developed from the treated larvae. The pupal malformation percent was $100.0 \%$ at the all concentrations used compared to $0.0 \%$ for the control group (Table 8 ).

From the aforementioned results it is obvious that the toxicity values of the tested acetone extracts of different plant parts of $C$. nocturnum based on $\mathrm{LC}_{50}$ values (Table 8 and fig. 2) may be arranged in a descending order as follows : leaves > stems. 
In general, the toxicity values of tested extracts of the different parts of $C$. nocturnum based on $\mathrm{Lc}_{50}$ values (Tables 5 and 8 ) may be arranged in a descending order as follows: Ethanolic extract (leaves) > acetone extract (leaves) > acetone extract (stems) $>$ ethanolic extract (stems).

Table (6): Effect of acetone extract of Cestrum nocturnum (leaves) on mortality percent of different stages of Culex pipiens.

\begin{tabular}{|c|c|c|c|c|c|c|c|}
\hline Conc. ppm & $\begin{array}{c}\text { Larval } \\
\text { mortality } \\
\%\end{array}$ & $\begin{array}{c}\text { Pupation } \\
\%\end{array}$ & $\begin{array}{c}\text { Pupal } \\
\text { Mortality } \\
\%\end{array}$ & $\begin{array}{c}\text { Malformed } \\
\text { pupae } \\
\%\end{array}$ & $\begin{array}{c}\text { Larval and } \\
\text { pupal Mortality } \\
\%\end{array}$ & $\begin{array}{c}\text { Adult } \\
\text { Emergence } \\
\%\end{array}$ & $\begin{array}{c}\text { Adult } \\
\text { Mortality } \\
\%\end{array}$ \\
\hline 2000 & 100.0 & - & - & & - & - & - \\
\hline 1500 & 93.3 & 6.7 & 100.0 & 100.0 & 100.0 & 0.0 & - \\
\hline 1000 & 73.3 & 26.7 & 87.5 & 87.5 & 96.7 & 12.5 & 100.0 \\
\hline 500 & 50.0 & 50.0 & 93.3 & 93.3 & 96.7 & 6.7 & 0.0 \\
\hline 250 & 26.7 & 73.3 & 90.9 & 90.9 & 93.3 & 9.1 & 0.0 \\
\hline Control & 10.0 & 90.0 & 0.0 & 0.0 & 10.0 & 100.0 & 0.0 \\
\hline
\end{tabular}

No. of tested larvae, Conc., ppm,.: see footnote of table (3).

Table (7): Effect of acetone extract of Cestrum nocturnum (stems) on mortality percent of different stages of Culex pipiens.

\begin{tabular}{ccccccc}
\hline $\begin{array}{c}\text { Conc. } \\
\text { ppm. }\end{array}$ & $\begin{array}{c}\text { Larval } \\
\text { mortality } \\
\text { \% }\end{array}$ & $\begin{array}{c}\text { Pupation } \\
\text { \% }\end{array}$ & $\begin{array}{c}\text { Pupal } \\
\text { Mortality } \\
\mathbf{\%}\end{array}$ & $\begin{array}{c}\text { Malformed } \\
\text { pupae } \\
\text { \% }\end{array}$ & $\begin{array}{c}\text { Larval and } \\
\text { Pupal Mortality } \\
\text { \% }\end{array}$ & $\begin{array}{c}\text { Adult } \\
\text { Emergence } \\
\text { \% }\end{array}$ \\
\hline $\mathbf{3 0 0 0}$ & 100.0 & - & - & - & - & - \\
$\mathbf{2 0 0 0}$ & 90.0 & 10.0 & 100.0 & 100.0 & 100.0 & 0.0 \\
$\mathbf{1 0 0 0}$ & 53.3 & 46.7 & 100.0 & 100.0 & 100.0 & 0.0 \\
$\mathbf{5 0 0}$ & 43.3 & 56.7 & 100.0 & 100.0 & 100.0 & 0.0 \\
$\mathbf{2 5 0}$ & 30.0 & 70.0 & 100.0 & 100.0 & 100.0 & 0.0 \\
$\mathbf{1 2 5}$ & 10.0 & 90.0 & 100.0 & 100.0 & 100.0 & 0.0 \\
\hline \hline Control & $\mathbf{6 . 7}$ & $\mathbf{9 3 . 3}$ & $\mathbf{3 . 6}$ & $\mathbf{0 . 0}$ & $\mathbf{1 0 . 0}$ & $\mathbf{9 6 . 4}$ \\
\hline
\end{tabular}

No. of tested larvae, Conc., ppm : see footnote of table (3).

Table (8): Relative efficiency of acetone extract of different parts of Cestrum nocturnum against $C$. pipiens larvae.

\begin{tabular}{lccc}
\hline \multicolumn{1}{c}{ Plant parts } & LC $_{50}(\mathbf{p p m})$ & Slope (b) & $\begin{array}{c}\text { Correlation } \\
\text { coefficient (r) }\end{array}$ \\
\hline Leaves & 484.2 & 0.0244 & 0.759 \\
\hline \hline Stems & 993.98 & 0.0294 & 0.9217 \\
\hline
\end{tabular}




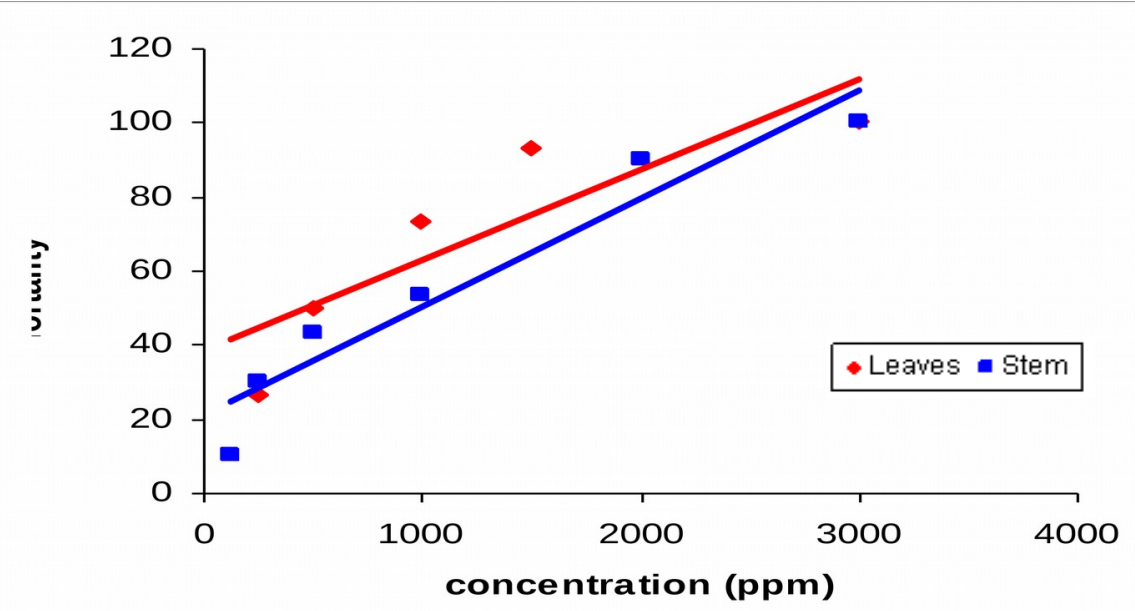

Fig. (2): Regression line of larval mortality of $C$. pipiens treated with different concentrations from acetone extracts of $C$. nocturnum. 


\section{Repellency / antifeedant action:}

\subsection{Ethanolic extract of leaves and stems:}

Table (9) indicated that the leaves extract had a more repellent activity against $C$. pipiens females than stems extract. The repellency action for leaves and stems extracts were 81.25 and $79.0 \%$ at the dose $3.6 \mathrm{mg} / \mathrm{cm}^{2}$, while; it recorded 67.7 and $54.7 \%$ at the dose $1.8 \mathrm{mg} / \mathrm{cm}^{2}$; respectively compared to $100 \%$ repellency for Off! at the dose $1.8 \mathrm{mg} / \mathrm{cm}^{2}$.

\subsection{Acetone extract of Leaves and stems:}

Table (10) showed that acetone extract of leaves and stems caused 86.8 and $83.1 \%$, respectively at the dose $3.6 \mathrm{mg} / \mathrm{cm}^{2}$. However, at the lowest dose $(1.8$ $\mathrm{mg} / \mathrm{cm}^{2}$ ) the two extracts caused 72.4 and $69.7 \%$; respectively compared to $100 \%$ repellency for Off! at the dose $1.8 \mathrm{mg} / \mathrm{cm}^{2}$.

\section{Morphogenetic effects:}

The different forms of morphogenetic effects as induced by the different plant extracts tested against the $3^{\text {rd }}$ instar larvae of $C$. pipiens are illustrated in Fig.(3) from A to $\mathrm{D}$ and can be summarized as follows:

A - pupal- adult intermediate resulted from larvae treated with acetone leaves and stems extracts (All concentrations used).

B - Deformed decolorized pupal- adult intermediate resulted from larvae treated with acetone extract of stems (500, 250 and 125ppm).

C - Half- ecdysed adult resulted from the treatment of the larvae with acetone leaves extract (250ppm).

D - Incompletely emerged adult with legs attached to the pupal skin, wings unequal and abdomen not completely segmented. This abnormality feature was obtained when larvae treated with ethanolic and acetone extracts (1000, 500 and 1000ppm), respectively.

Table (9): Repellency / antifeedant effect of ethanolic extract of Cestrum nocturnum on Culex pipiens.

\begin{tabular}{cccccccc}
\hline $\begin{array}{c}\text { Plant } \\
\text { parts }\end{array}$ & $\begin{array}{c}\text { Dose } \\
\left(\mathbf{m g} / \mathbf{c m}^{2}\right)\end{array}$ & $\begin{array}{c}\text { No. of } \\
\text { tested } \\
\text { females }\end{array}$ & $\begin{array}{c}\text { No. of } \\
\text { fed }\end{array}$ & \% & $\begin{array}{c}\text { No. of } \\
\text { unfed }\end{array}$ & \% & $\begin{array}{c}\text { Repellency } \\
\text { \% }\end{array}$ \\
\hline \multirow{2}{*}{ Leaves } & 3.6 & 28 & 5 & 17.9 & 23 & 82.1 & 81.3 \\
& 1.8 & 26 & 8 & 30.8 & 18 & 69.2 & 67.7 \\
Stem & 3.6 & 20 & 4 & 20.0 & 16 & 80.0 & 79.0 \\
Off & 1.8 & 21 & 9 & 42.9 & 12 & 57.1 & 54.9 \\
& 1.8 & 25 & 0.0 & 0.0 & 25 & 100.0 & 100.0
\end{tabular}


LARVICIDAL AND REPELLENT EFFECT OF LEAF AND STEM

\begin{tabular}{|c|c|c|c|c|c|c|c|}
\hline Control & ב---- & 21 & 20 & 95.2 & 1 & 4.8 & 0.0 \\
\hline \multicolumn{8}{|c|}{$\begin{array}{l}\text { Table (10): Repellency / antifeedant effect of acetone extract of Cestrum nocturnum on } \\
\text { Culex pipiens. }\end{array}$} \\
\hline $\begin{array}{l}\text { Plant } \\
\text { parts }\end{array}$ & $\begin{array}{c}\text { Dose } \\
\left(\mathbf{m g} / \mathbf{c m}^{2}\right)\end{array}$ & $\begin{array}{c}\text { No. of } \\
\text { tested } \\
\text { females }\end{array}$ & $\begin{array}{c}\text { No. } \\
\text { of } \\
\text { fed }\end{array}$ & $\%$ & $\begin{array}{l}\text { No. of } \\
\text { unfed }\end{array}$ & $\%$ & $\begin{array}{c}\text { Repellency } \\
\%\end{array}$ \\
\hline \multirow[b]{2}{*}{ Leaves } & 3.6 & 24 & 3 & 12.5 & 21 & 87.5 & 86.8 \\
\hline & 1.8 & 23 & 6 & 26.1 & 17 & 73.9 & 72.4 \\
\hline \multirow[b]{2}{*}{ Stem } & 3.6 & 25 & 4 & 16.0 & 21 & 84.0 & 83.1 \\
\hline & 1.8 & 28 & 8 & 28.6 & 20 & 71.4 & 69.7 \\
\hline Off & 1.8 & 25 & 0.0 & 0.0 & 25 & 100.0 & 100.0 \\
\hline Control & ----- & 18 & 17 & 94.4 & 1 & 5.6 & 0.0 \\
\hline
\end{tabular}
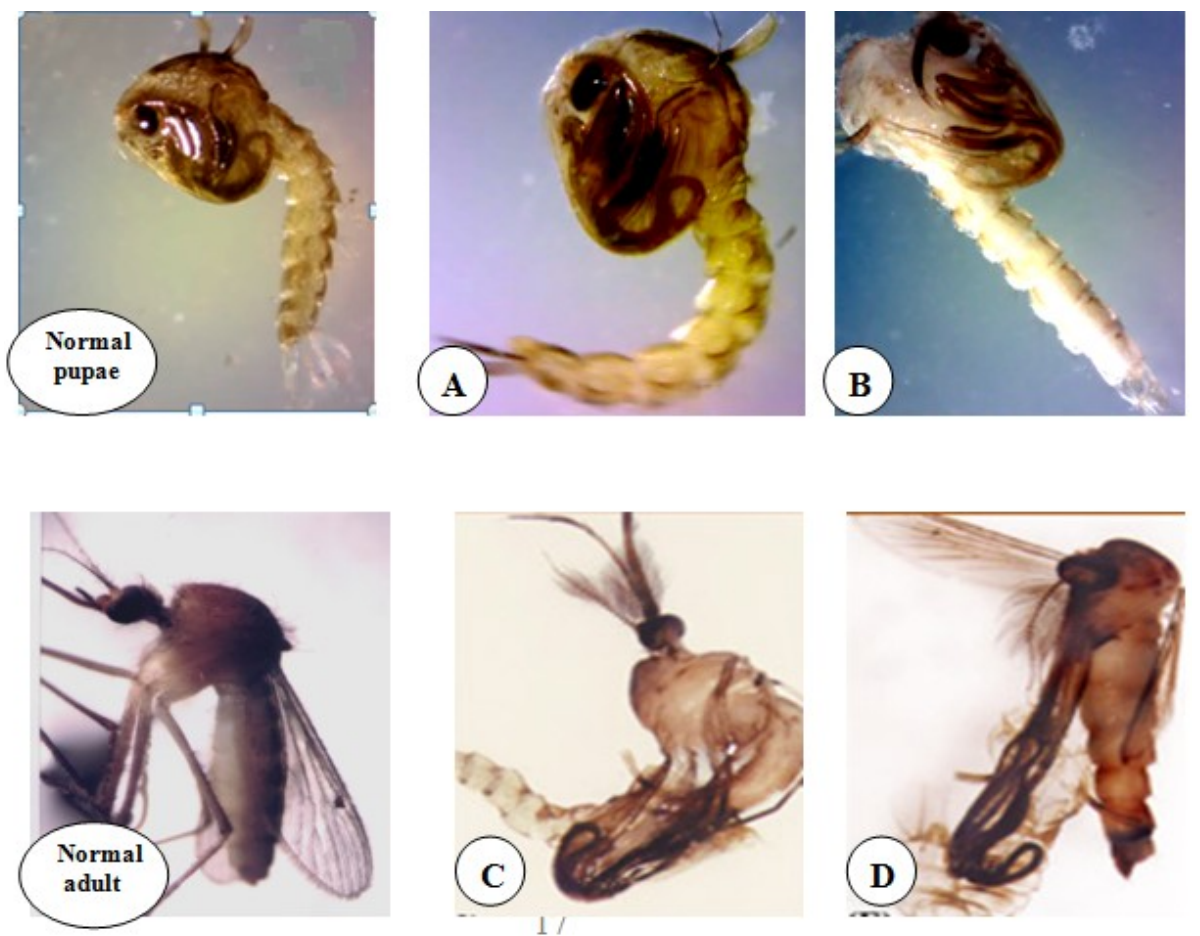
Fig. (3): Malformative effects in C. pipiens pupae and adult as induced by the plant extract tested (160 X). Explanation of figures (See result 4).

\section{Discussion}

The plants tested in the present study are known to be eco - friendly and are not toxic to vertebrates. Moreover, it is clearly proved that crude or partially purified plant extracts are less expensive and highly efficacious for the control of mosquitoes rather than the purified compounds or extracts (Jang et al., 2002 ; Cavalcanti et al., 2004 and Maurya et al. 2009). The present study showed high bioactivity of the different extracts from plants which are grown widely in Egypt. Such results may offer an opportunity for developing alternatives to rather expensive and environmentally hazardous organic insecticides.

Ethanolic and acetone extracts of the different parts of the C. nocturnum plant against the larval and adult stages of $C$. pipiens clearly affected the various biological and repellency aspects as follows:

\section{Biological activity of plant extracts against the larval stage:}

\subsection{Larvicidal activity:}

The present study showed that, the toxicity of the tested plant extracts against $3^{\text {rd }}$ larval instar was varied according to plant part used and concentration of the extract. The larval mortality percent was increased by increasing extract concentration for all plant extracts tested. The toxicity of ethanolic and acetone extracts based on $\mathrm{LC}_{50}$ was leaves $>$ stems. These results are in consistent with the previously mentioned suggestions of Sukumar et al. (1991) and Maurya et al. (2009). In all larvicidal assays, the methanol extract of $C$. nocturnum leaves extracted with percolation and its fractions presented higher larvicidal activity (Jawale et al. 2010).

Several plant extracts other than those used in the present study had been tested against different species of mosquitoes by many authors worldwide. The tested plant extracts on larval mortality of $C$. pipiens were in agreement with the results obtained by Shalaby et al. (1998), Pelah et al. (2002), Jeyabalan et al (2003), Nathan et al. (2005 \& 2006), Sharma et al. (2006b), Coria et al. (2008), Maurya et al. (2009). The hexane, ethyl acetate and methanol using soxhlet and percolation extraction separately of $C$. nocturnum were tested against the $3^{\text {nd }}$ instar larvae of Aedes aegypti at different concentrations by Jawale et al. (2010); they recorded that among the 
three extracts of $C$. nocturnum, percolation method extracts showed effective larvicidal activity over the soxhlet method. Methanol extract exhibit significant larvicidal activity causing $100 \%$ mortality in a concentration of $100 \mu \mathrm{g} / \mathrm{mL}$. However, the present study showed that the acetone extract of this plant (leaves and stems) caused $100 \%$ larval mortality of C. pipiens at concentration 500ppm, respectively.

\subsection{Pupation percent, pupal mortality and adult emergence:}

In the present study, a remarkable decrease in the pupation percent was induced by all plant extracts tested. The pupation\% was decreased as the concentration of the plant extract increased. Moreover, the pupation rate was found to be plant part - and solvent used in extraction - dependent.

The present study showed that the toxicity of plant extracts tested has been extended to the pupae, where $100 \%$ pupal mortality was induced by acetone stems extract. In addition, the acetone leaves and stems extracts tested induced a remarkable reduction in the \% of adult emerged from the pupae produced from treated larvae. The reduction was concentration- dependent. These results are comparable with earlier results of Shalaby et al. (1998) using peel oils of lemon, grapefruit and naval orange against $C$. pipiens larvae, El - Bokl (2003) using the neem, Azadirachta indica extract against $C$. pipiens larvae, Jeyabalan et al (2003) using water extracts of E. crassipes and Ar. Monosperma against C. pipiens larvae, Nathan et al. (2006) using methanolic extracts of leaves and seeds of Melia azedarach against $A$. stephensi larvae, Sharma et al. (2006 a \& b) using petroleum ether extract of Artemisia annua against An. stephensi and Culex quinquefasciatus larvae, respectively and Pavela (2009) using essential oils from 22 aromatic plant species against Culex quinquefasciatus Say (Diptera: Culicidae).

\subsection{Survivorship of the resulted adults:}

Results obtained in the present study indicated that the toxicity of acetone extracts tested against the $3^{\text {rd }}$ instar larvae of $C$. pipiens was extended to the produced adults causing mortality reached to $100 \%$ for acetone leaves extract. Similar results were obtained by Shalaby et al. (1998) using peel oils of lemon, grapefruit and naval orange against $C$. pipiens larvae, Jeyabalan et al. (2003) using methanol extract of Pelargonium citrosa leaf against A. stephensi, Nathan et al. (2005) using the neem Azedirachta indica extract against A. stephensi and Nathan 
et al. (2006) using methanolic extracts of leaves and seeds from the chinaberry tree Melia azedarach against $A$. stephensi.

\subsection{Morphogenetic effects:}

In the present study almost all extracts of plant parts tested against the $3^{\text {rd }}$ instar larvae of $C$. pipiens induced some morphological abnormalities in pupae. The malformed pupae were not able to develop normally and died. Also, the present results showed that the percent and degree of malformation among pupae were dependent on the conc. of the plant extract and solvent used in extraction. Similar observations were obtained by different plant extracts against different mosquito species in earlier studies. Similary, Abahussain (1999) using Calotropis procera extracts against $C$. pipiens and A. multicolor observed morphological abnormalities among pupae. El-Bokl (2003) recorded varying degrees of morphogenetic abnormalities in immature and adult stages of $C$. pipiens when larvae were treated with the neem, Azadirachta indica extract.

\section{Repellency/antifeeding activity:}

All the concentrations of plant extracts used in the present study exhibited repellency activity against the starved female adults of $C$. pipiens. The repellent action of the plant extracts tested was varied depending on plant part, solvent used in extraction and the dose of the extract. The present study indicated that the acetone extraction of the plant used was more effective in exhibiting the repellent action against the mosquito tested as compared with the ethanol extraction and showed less repellency percent than a commercial formulation, N,N-diethyl-m-methylbenzamide (DEET).

Many plant extracts and essential oils manifest repellency activity against different mosquito species. The present results are in accordance with such results obtained by Sharma et al. (1995) using neem oils against mosquito bites of Anopheles spp., Culex spp. And Aedes spp., Govere et al. (2000) using extracts of fever tea (Lippia javanica) rose geranium (Pelargonium reniforme) and lemon grass (Cymbopogon excavatus) against $A$. arabiensis, Kim et al., (2002) using ethanol extract of fruits from Foeniculum vulgarea against hungry Aedes aegypti females, Jeyabalan et al., (2003) using methanol extracts of Pelargonium citrosa against $A$. stephensi, Yang et al. (2004) using methanol extracts from 23 aromatic medicinal plant species against female blood - starved Aedes aegypti, Nathan et al. (2006 b) 
using extracts of the neem Azadirachta indica and methanolic extracts of leaves and seeds from the chinaberry tree, Melia azedarach against $A$. stephensi, Choochote $\boldsymbol{e t}$ al. (2007) using repellent activity of selected essential oils from ten plant species against Aedes aegypti and Chio and Yang (2008) using neem tree (Azadirachta indica) oil against the Asian tiger mosquito (Aedes albopictus).

In general, it could be concluded that almost the plant extracts used in the present study act as larvicidal, and inhibited growth and emergence of the mosquito vector, C. pipiens. Furthermore, the results of the present study may contribute to a reduction in the application of synthetic insecticides, which in turn increases the opportunity for natural control of various medically important pests by botanical pesticides. These botanical pesticides are often active against specific target insects, less expensive, easily biodegradable to non - toxic products and potentially suitable for use in mosquito control program (Alkofahi et al., 1989 and Su and Mulla, 1999).

Further studies on the tested plants including mode of action, synergism with the biocides under field condition are needed.

\section{References}

1.Abahussain, M.O. (1999): Effect of Sorghum bicolor and Nerium oleander extracts on of the grey flesh fly Parasarcophaga argyrostoma (Diptera: sarcophagidae). J. Egypt. Ger. Soc. Zool., 28(2): 233 - 243.

2.Abbott, W.S. (1925): A method for computing the effectiveness of an insecticide. J. Econ. Entomol., $18: 265-277$.

3.Alkofahi, A.; Rupprecht, J.K.; Anderson, J.E.; Mclaughlin, J.L.; Mikolajczak, K.L. and Scott, B.A. (1989): Insecticides of plant orign, American chemical society, Washington, DC, $25-43$.

4.Briggs, J.N.(1960): Reduction of adult house fly emergence by the effective Bacillus sp. on the development of immature forms. J. Insect pathology. $2: 418-432$.

5.Cavalcanti, E.S.; Morais, S.M.; Lima, M.A. and Santana, E.W. (2004): Larvicidal activity of essential oils from Brazilian plants against Ae. aegypti L. Mem. Inst. Oswaldo. Cruz., 99(5) : $541-4$.

6.Chio, E.H. and Yang, E.C. (2008): A bioassay for natural insect repellents. Journal of AsiaPacific Entomology 11 : 225-227.

7.Choochote, W.; Chaithong, U.; Kamsuk, K. ; Jitpakdi, A.; Tippawangkosol, P.; Tuetun, B.; Champakaew, D. and Pitasawat, B. (2007): Repellent activity of selected essential oils against Aedes aegypti. Fitoterapia 78 : 359-364. 
8.Corbel, V., Duchon, S., Zaim, M., Hougard, J.M., (2004): Dinotefuran: a potential neonicotinoid insecticide against resistant mosquitoes. J. Med. Entomol. 41 (4), 712-717.

9.Coria, C. ; Almiron, W. ; Valladares, G. ; Carpinella, C. ; Ludueña, F. ; Defago, M. and Palacios, S. (2008): Larvicide and oviposition deterrent effects of fruit and leaf extracts from Melia azedarach L. on Aedes aegypti (L.) (Diptera: Culicidae). Bioresource Technology 99 : 3066-3070.

10.Darwish, M. and Hoogstraal, H. (1981): Arboviruses infesting human and lower animals in Egypt., A review of thirty years of research. J. Egypt. Pub. Hlth. Assoc., 56 : 1 - 112.

11.El - Bokl, M.M. (2003): Latent toxicity of azadirachtin treatment on C. pipiens (Diptera : Culicidae). J. Egypt. Acad. Soc. Environ. Develop., 3(1): 63 - 74.

12.Finney, D.J. (1971): Probit analysis Third edition. Cambridge Univ. Press., 333 p.

13.Gad, A.M.; Hammad, R.E. and Farid, H.A. (1996): Uptake and development of Wucheria bancrofti in C. pipiens L. and Ae. caspius Pallas. J. Egypt. Soc. Parasitol., 26(2): 305 314.

14.Ghosh A, Chandra G.(2006): Biocontrol efficacy of Cestrum diurnum L. (Solanaceae: Solanales) against the larval forms of Anopheles stephensi. Nat Prod Res. 20: 371-79.

15.Ghosh A, Chowdhury N, Chandra G.(2008): Laboratory evaluation of phytosteroid compound of mature leaves of Day Jasmine (Solanaceae: Solanales) against larvae of Culex quinquefasciatus (Diptera: Culicidae) and nontarget organisms. Parasitol Res. 103: 271-77.

16.Govere, T.A.; Durrheim, D.N.; Du, T.N.; Hunt, R.H. and Coetzee, M. (2000): Local plants as repellents against $A$. arabiensis, in Mpumalanga Province, South Africa. Cent. Afr. J. Med., 46(8): 213 - 6.

17.Jang, Y.S.; Baek, B.R.; Yang, Y.C.; Kim, M.K. and Lee, H.S. (2002): Larvicidal activity of leguminous seeds and grains against Ae. aegypti and C. pipiens pallens. J. Am. Mosq. Control. Assoc., 18(3): 210 - 3.

18.Jawale, C.; Kirdak,R. and Dama, L. (2010): Larvicidal activity of Cestrum nocturnum on Aedes aegypti. Bangladesh J. Pharmacol ., 5: 39-40

19.Jeyabalan, D.; Arul, N. and Thangamathi, P. (2003): Studies on effects of Pelargonium citrosa leaf extracts on malarial vector, A. stephensi Liston. Bioresour. Technol., 89(2): $185-9$.

20.Kasap, M. and Demirhan (1992): The effect of various larval foods on the rate of adult emergence and fecundity of mosquitoes. Turkiye Parazitologi Dergisi., 161 : 87 - 97.

21.Kim, D.H.; Kim, S.I.; Chang, K.S. and Ahn, Y.J. (2002): Repellent activity of constituents identified in Foeniculum vulgare fruit against Ae. aegypti (Diptera : Culicidae). J. Agric. Food. Chem., 50(24): $6993-6$. 
22.Lentner, C.; Lentner, C. and Wink, A. (1982): Studentis t- distribution tables. In Geigy scientific Tables Vol. 2. International Medical and Pharmaceutical information, Ciba Geigy Limited, Basal, Switzerland.

23.Maurya, P. ; Sharma, p.; Mohan, L. ; Batabyal L. and Srivastava, C.N. (2009): Evaluation of the toxicity of different phytoextracts of Ocimum basilicum against Anopheles stephensi and Culex quinquefasciatus. Journal of Asia-Pacific Entomology 12 : 113-115.

24.Nathan, S.S.; Kalaivani, K. and Murugan, k. (2005): Effects of neem limonoids on the malaria vector A. stephensi Liston (Diptera: Culicidae). Acta Trop. 96(1): 47-55

25.Nathan, S.S.; Savitha, G.; George, D.K.; Narmadha, A.; Suganya, L. and Chung, P.G. (2006): Efficacy of Melia azedarach L. extract on the malarial vector A. stephensi Liston (Diptera: Culicidae). Bioresour Technol. 79: 1316 - 1323.

26.Pavela, R. (2009): Larvicidal property of essential oils against Culex quinquefasciatus Say (Diptera: Culicidae). Industrial Crops and Products 30 : 311-315.

27.Pelah, D.; Abramovich, Z.; Markus, A. and Wiesman, Z. (2002): The use of commercial saponin from Quillaje saponaria bark as a natural larvicidal agent against Ae. aegypti and C. pipiens. J. Ethnopharmacol., 81(3):407-9.

28.Rohani, A., Chu,W.L., Saadiyah, I., Lee, H.L., Phang, S.M., (2001): Insecticide resistance status of Aedes albopictus and Aedes aegypti collected from urban and rural in major towns of Malaysia. Trop. Biomed. 18 (1), 29-39.

29.Shalaby, A.A.; Allam, K.A.M.; Mostafa, A.A. and Fahmy, S.M.E. (1998): Insecticidal properties of citrus oils against C. pipiens and M. domestica. J. Egypt. Soc. Parasitol., 28(2): 595 - 606.

30.Sharma, S.K.; Dua, V.K. and Sharma, V.P. (1995): Field studies on the mosquito repellent action of neem oil. Southeast Asian J. Trop. Med. Public. Health. 26(1):180-2.

31.Sharma, p.; Mohan, L. and Srivastava, C.N. (2006 a): Phytoextract-induced developmental deformities in malaria vector. Bioresource Technology 97: 1599-1604.

32.Sharma, p.; Mohan, L. and Srivastava, C.N. (2006 b): Growth Inhibitory Nature of Artemisia annua Extract against Culex autnauetesctetus (Say). J. Asia-Pacific Entomol. 9(4): 389-395.

33.Su, T. and Mulla, M.S. (1999): Oviposition bioassay responses of $C$. tarsalis and $C$. quinquefasciatus to neem products containing azadirachtin. Entomol. Exp. Appl., 91: 337 -345 .

34.Sukumar, K.; Perich, M.J. and Boobar, L.R. (1991): Botanical derivatives in mosquito control: A review. Am. Mosq. Control. Assoc., 7(2): 210 - 237.

35.Taubes, G., (2000) Vaccines. Searching for a parasites weak spot. Science 290 (5491), 434-437. 
36.Wattanachai, P., Tintanon, B., (1999): Resistance of Aedes aegypti to chemical compounds in aerosol insecticide products in different areas of Bangkok, Thailand. Commun. Dis. J. 25, 188-191.

37.Yang, Y.C.; Lee, E.H.; Lee, H.S.; Lee, D.K. and Ahn, Y.G. (2004): Repellency of aromatic medicinal plant extracts and a steam distillate to Ae. aegypti. J. Am. Mosq. Control. Assoc., 20(2): $146-9$. 


\section{التأثير الطارد و السمي لمستخلصات الورقة و الساق لنبات مسك الليل ضد كيولكس ببينز (ثنائية الأجنحة:كيولسيدى ورئ)}

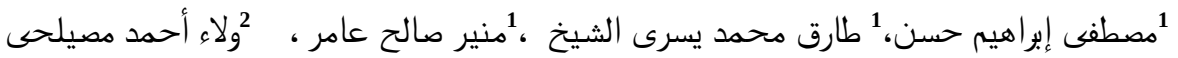

$$
\text { و أحمد زينهم شحاتة }
$$

1 قسم علم الحيوان- كلية العلوم- جامعة الأزهر-القاهرة (بنين)

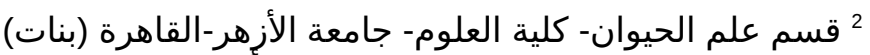

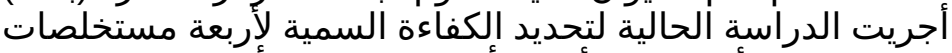

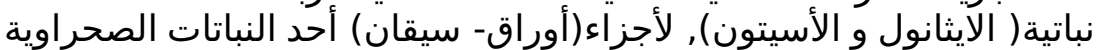

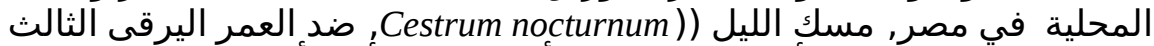

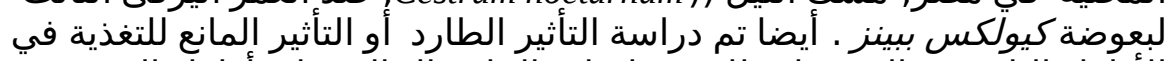

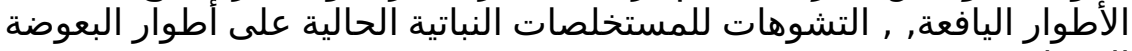

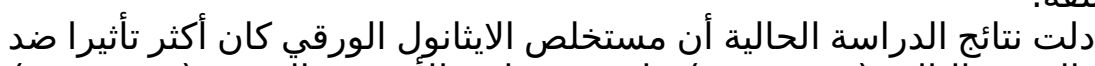

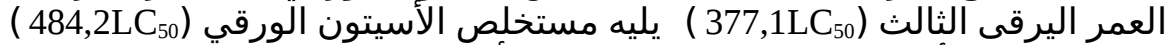

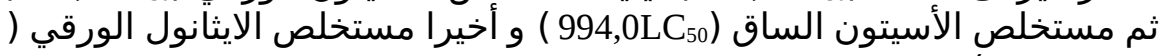
(1043,8LC أوضحت نتائج الدراسة الحالية نقصا واضحا فى معدل التعذر و نسبة ظهور

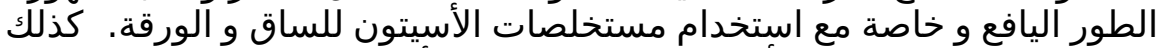

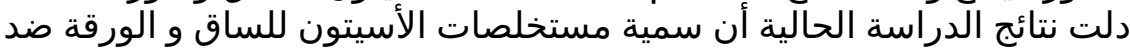

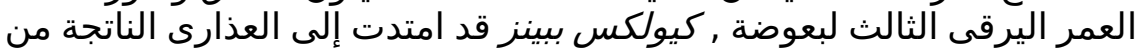

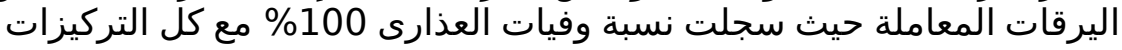

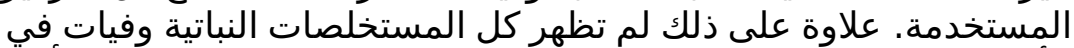

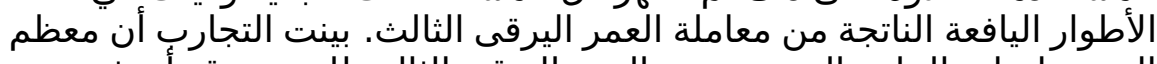

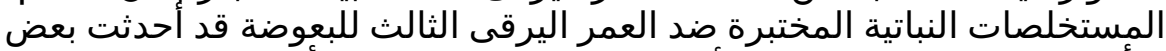

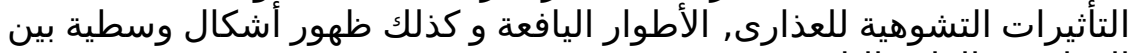

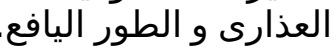

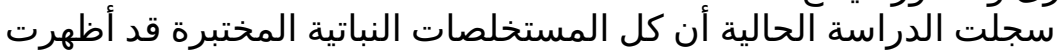

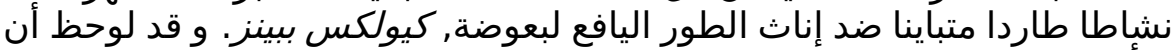

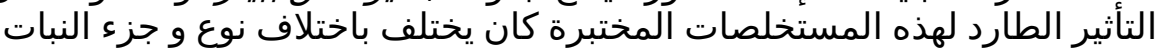

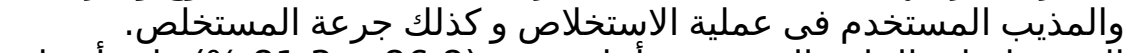
المستخلصات النباتية التي تحدث عملية أعلى نسبة المبلى (86,8, و 81,3 \%

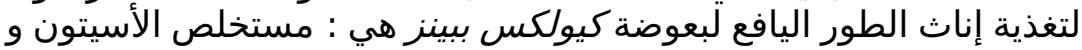

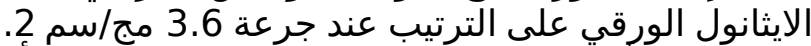

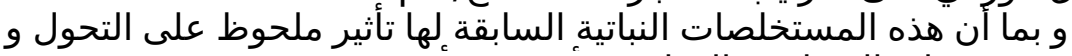
لها تأثير سمى بما أن عذه اليرقات المستخلي و العذارى

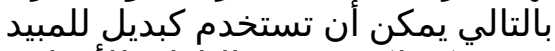
بعوضة كيولكس بيمن النس تبنز الناقلة للأمراض للمبديد 